\title{
Matrix Phase in Lower Bainite and
}

\section{Tempered Martensite}

\author{
by F. E. Werner, B. L. Averbach, and Morris Cohen
}

$\mathbf{T}_{\mathrm{B}}$ HAT bainite formed near the $M_{s}$ temperature bears a striking resemblance to martensite tempered at the same temperature has been shown by the electron microscope. ${ }^{1}$ By means of electron diffraction," it has been established that $\epsilon$ carbide and cementite are present in bainite formed at $500^{\circ} \mathrm{F}$ $\left(260^{\circ} \mathrm{C}\right)$; these carbides are also found in martensite tempered at $500^{\circ} \mathrm{F}\left(260^{\circ} \mathrm{C}\right) .^{2,3}$

The investigation reported here is concerned with an X-ray study of the matrix phases in lower bainite and tempered martensite. These phases have turned out to be dissimilar in structure; the matrix of bainite is body-centered-cubic while that of tempered martensite is body-centered-tetragonal.

A vacuum-melted Fe-C alloy containing 1.43 pct $\mathrm{C}$ was studied. Specimens of $1 / 8$ in. diam were sealed in evacuated silica tubing and austenitized at $2300^{\circ} \mathrm{F}$ $\left(1260^{\circ} \mathrm{C}\right)$ for $24 \mathrm{hr}$. One specimen was quenched into a salt bath at $410^{\circ} \pm 7^{\circ} \mathrm{F}\left(210^{\circ} \pm 4^{\circ} \mathrm{C}\right)$, held for $16 \mathrm{hr}$, and cooled to room temperature. The structure consisted of about 90 to 95 pct bainite, the remainder being martensite and retained austenite. A second specimen was quenched from the austenitizing temperature into iced brine and then into liquid nitrogen. It consisted of about 90 pct martensite and 10 pct retained austenite. The latter specimen was tempered for $10 \mathrm{hr}$ at $410^{\circ} \pm 2^{\circ} \mathrm{F}$ $\left(210^{\circ} \pm 1^{\circ} \mathrm{C}\right)$.

The specimens were then fractured along prior austenite grain boundaries (grain size about $2 \mathrm{~mm}$ diam) by light tapping with a hammer. Single austenite grains, mostly transformed, were etched to about $0.5 \mathrm{~mm}$ diam and mounted in a Unicam single crystal goniometer, which allowed both rotation and oscillation of the sample. Lattice parameters were measured by the technique of Kurdjumov and Lyssak. ${ }^{4}$ This method takes advantage of the fact that martensite and lower bainite are related to austenite by the Kurdjumov-Sachs orientation relationships." Thus, the (002) and the (200) (020) reflections can be recorded separately, permitting the $c$ and $a$ parameters to be determined without interference from overlapping reflections.

According to these findings, the matrix phase in bainite is body-centered-cubic and, within experimental error, has the same lattice parameter as ferrite $(2.866 \AA)$. On the other hand, martensite, tempered as above, retains some tetragonality, with a $c / a$ ratio of $1.005 \pm 0.002$.

Most workers in the past have assumed that bainite is generated from austenite as a supersaturated phase, but the nature of this product has not been established. The question arises as to

F. E. WERNER is Research Engineer, Research Laboratories, Westinghouse Electric Corp., Pittsburgh. B. L. AVERBACH and M. COHEN, Members AIME, are Associate Professor and Professor, respectively, Dept. of Metallurgy, Massachusetts Institute of Technology, Cambridge, Mass.

TN 357E. Manuscript, May 28, 1956. whether bainite initially has a tetragonal structure and then tempers to cubic, or if it forms directly as a cubic structure. If it forms with a tetragonal lattice, it might well be expected to temper to the cubic phase at about the same rate as tetragonal martensite.

The martensitic specimen used here was given approximately the same tempering exposure, $10 \mathrm{hr}$ at $410^{\circ} \mathrm{F}$, as suffered by the greater part of the bainite during the isothermal transformation. About 50 pct bainite was formed in $6 \mathrm{hr}$ at $410^{\circ} \mathrm{F}$. On tempering at this temperature, martensite reduces its tetragonality within a few minutes to a value corresponding to 0.30 pct $\mathrm{C}^{{ }^{8}}$ Further decomposition proceeds slowly, and after $10 \mathrm{hr}$ the $c / a$ ratio is still appreciable, i.e., 1.005. Thus, even if the bainite were to form as a tetragonal phase with a tetragonality corresponding to only 0.30 pct $C$, which might be assumed to coexist with $\epsilon$ carbide, ${ }^{7}$ it would not be expected to become cubic in this time. It seems very likely, therefore, that bainite forms from austenite as a body-centered-cubic phase and does not pass through a tetragonal transition. The carbon content of the cubic phase has not been determined, but it could easily be as high as 0.1 pct, within the experimental uncertainty of the latticeparameter measurements.

It has been postulated ${ }^{8}$ that retained austenite decomposes on tempering into the same product as martensite tempered at the same temperature. There is now considerable doubt on this point. The isothermal transformation product of both primary and retained austenite at the temperature in question here is bainite, ${ }^{y}$ and the present findings show that bainite and tempered martensite do not have the same matrix.

\section{Acknowledgments}

The authors would like to acknowledge the financial support of the Instrumentation Laboratory, Massachusetts Institute of Technology, and the United States Air Force.

\section{References}

1 Electron Microstructure of Steel. Proceedings ASTM, 1950, vol. 50, p. 444

2 A. E. Austin and C. M. Schwartz: Electron-Diffraction Study of Iron Carbides in Bainite and Tempered Martensite. Proceedings ASTM, 1952, vol. 52, p. 592 .

(t) Transformations in the Tempering of vol. $169, \mathrm{p}, 26$. vol. 169, p. 26. to the Study of Tempered Martensite. Journal Iron and Steel Inst. 1947 , vol. 156, p. 29 .

S B. S. Lement, B. L. Averbach, and M. Cohen: Microstructural Changes on Tempering Iron-Carbon Alloys. ASM Trans., 1954, vol.

46, p. 851 . sition of Austenite to Pearlite, Bainite, and Martensite. AIME

Trans., 1942, vol. 150, p. 211 . of Iron-Carbon Martensite Crystals. ASM Trans., 1957, vol. 49. $\checkmark$ C. S. Roberts, B. L. Averbach, and M. Cohen: The Mechanism and Kinetics of the First Stage of Tempering. ASM Trans., 1953, vol. 45 , p. 576 .

$y$ J. Crangle and W. Sucksmith: Magnetic Analysis of Iron-Carbon Alloys. Journal Iron and Steel Inst., 1951, vol. 168, p. 141.

${ }^{10} \mathrm{R}$. W. Balluffi, M. Cohen, and B. L. Averbach: The Tempering of Chromium Steels. ASM Trans., 1951, vol. 43, p. 497. 